\title{
Polymerization of $o$-Trimethylsilylphenylacetylene Initiated by a Tungsten Carbene Complex
}

\author{
Der-Jang Liaw, ${ }^{\dagger}$ Kai-Ruey Hu, Hao-Hsien Chiang, \\ and En-Tang KANG* \\ Department of Chemical Engineering, National Taiwan Institute of Technology, \\ Taipei, Taiwan 106, Republic of China \\ * Department of Chemical Engineering, National University of Singapore, \\ Kent Ridge, Singapore 0511
}

(Received August 22, 1994)

\begin{abstract}
The polymerization of $o$-trimethylsilylphenylacetylene $\left(o-\mathrm{Me}_{3} \mathrm{SiPA}\right)$ initiated by tungsten carbene complex (I) was investigated under various conditions. Both a larger molar mass and larger yield of polymer were obtained in $\mathrm{CCl}_{4}$ and $\mathrm{CHCl}_{3}$ and in the presence of a Lewis acid such as $\mathrm{AlCl}_{3}$. The higher the temperature and the lower the initiator concentration, the larger was the molar mass of the polymer. The molar mass increases with concentration of cocatalyst $\mathrm{SnCl}_{4}$ and shows a maximum value for a ratio $\left[\mathrm{SnCl}_{4}\right] /[\mathrm{I}]=1$. Moreover, when a solution of tungsten carbene complex in $\mathrm{CCl}_{4}$ was irradiated with UV light, the molar mass was remarkably enhanced. Kinetic orders and apparent rate constants were determined by gas chromatography. According to thermogravimetric results for poly $\left(o-\mathrm{Me}_{3} \mathrm{SiPA}\right)$, there is no significant interaction between the polymer and oxygen below $260^{\circ} \mathrm{C}$. Above $260^{\circ} \mathrm{C}$, the loss of mass in the presence of oxygen follows a two-step process. X-Ray diffraction measurements show that poly $\left(o-\mathrm{Me}_{3} \mathrm{SiPA}\right)$ has an amorphous structure.
\end{abstract}

KEY WORDS $o$-Trimethylsilylphenylacetylene / Tungsten Carbene Complex / Apparent Rate Constant / $\mathrm{CCl}_{4}$ / TGA / Cocatalyst /

Acetylene derivatives such as 1-heptyne, phenylacetylene and tert-butylacetylene are polymerized by tungsten carbene complex (I) to produce the corresponding polymers with larger molar mass. ${ }^{1-5}$ Catalyst (I) relatively easy to prepare and to handle,<smiles>COC(=O)N1CCCCC1</smiles>

(I)

has satisfactory thermal stability. ${ }^{6,7}$ The intramolecular coordination in the carbene complex

\footnotetext{
${ }^{\dagger}$ To whom all correspondence should be addressed.
}

(I) appears to increase its stability and facilitate complexation of the first alkyne unit. ${ }^{1-5,8}$

Several substituted polyacetylenes have been synthesized using groups 5 and 6 transitionmetal catalysts. ${ }^{9,10}$ Among those polymers are Si-containing polyacetylenes, some of which exhibit unique properties not observed in hydrocarbon polyacetylenes. For example, poly[1-(trimethylsilyl)-1-propyne] [poly(TMSP)] shows extremely high gas permeability ${ }^{1,12}$ and ethanol perselectivity in the ethanol/water pervaporation. ${ }^{13,14}$ Masuda reported that poly(o-trimethylsilylphenylacetylene) [poly $(o-$ $\left.\left.\mathrm{Me}_{3} \mathrm{SiPA}\right)\right]$ has a larger molar mass than that of poly(phenylacetylene) with transition metal catalysts. ${ }^{15}$ This indicates that the ortho sub- 
stituent favors increased molar mass of the polymer because of its steric hindrance. Good photoconductive properties were observed in poly $\left(o-\mathrm{Me}_{3} \mathrm{SiPA}\right) .{ }^{16}$ Detailed kinetic experiments and mechanisms have never been reported.

We describe here comprehensive results on the polymerization of $o-\mathrm{Me}_{3} \mathrm{SiPA}$ with this tungsten carbene complex (I) under various conditions. The effects of concentration of cocatalyst on the molar mass were examined. The kinetic order and apparent rate constants were investigated with a gas chromatography (GC). The mechanism and thermal properties of $\operatorname{poly}\left(o-\mathrm{Me}_{3} \mathrm{SiPA}\right)$ are discussed.

\section{EXPERIMENTAL}

\section{Monomer Preparation}

The monomer $\left(o-\mathrm{Me}_{3} \mathrm{SiPA}\right)$ was prepared according to the following scheme with the methods of Brandsma ${ }^{17}$ and Masuda et al. ${ }^{15}$ :
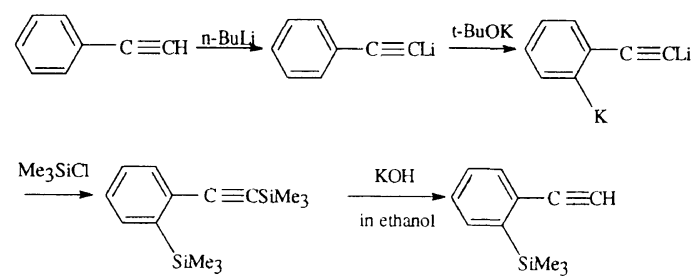

The monomer $\left(o-\mathrm{Me}_{3} \mathrm{SiPA}\right)$ was carefully distilled: bp $85^{\circ} \mathrm{C}(1.3 \mathrm{kPa})$ [lit. ${ }^{15,17} 85^{\circ} \mathrm{C}(1.3$ $\mathrm{kPa})$ ]; yield $78.8 \%$; purity $>99.9 \%$ (by GC).

The monomer ( $\left.o-\mathrm{Me}_{3} \mathrm{SiPA}\right)$ thus obtained was characterized by analytical techniques using IR, ${ }^{1} \mathrm{H}$ NMR, ${ }^{13} \mathrm{C}$ NMR, and ${ }^{29} \mathrm{Si}$ NMR spectra. ${ }^{18-20}$ IR: $v / \mathrm{cm}^{-1} \equiv \mathrm{C}-\mathrm{H}_{\text {str }} 3310$, C$\mathrm{H}_{\text {str }} 2900-3060, \mathrm{C} \equiv \mathrm{C}_{\text {str }} 2130, \mathrm{Si}-\mathrm{CH}_{3 \text { deform }}$ $1245, \mathrm{Si}-$ phenyl 1117 , methyl rocking $834, \mathrm{Si}-$ $\mathrm{CH}_{3 \text { str }}$ 751, 1,2-disubstituted aromatic 721. In the ${ }^{1} \mathrm{H}$ NMR spectrum $\left(\mathrm{CDCl}_{3} \delta / \mathrm{ppm}, \mathrm{TMS}\right)$ of the monomer appear sharp signals at 0.51 $\left(\mathrm{s}, 9 \mathrm{H}, \mathrm{Si}\left(\mathrm{CH}_{3}\right)_{3}\right), 3.29$ (s, $\left.1 \mathrm{H}, \mathrm{HC} \equiv \mathrm{C}-\right), 7.4$ and $7.61(2 \mathrm{~m}, 4 \mathrm{H}, \mathrm{ArH}) .{ }^{21}$ The ${ }^{13} \mathrm{C}$ NMR spectrum $\left(\mathrm{CDCl}_{3}\right)$ of the monomer exhibits signals of methyl carbons $\delta-1.079$, of $s p$ car-

$$
\begin{aligned}
& \mathrm{W}(\mathrm{CO})_{6}+\mathrm{BrMgCH}_{2}-\mathrm{CH}_{2}-\mathrm{CH}=\mathrm{CH}_{2} \\
& \frac{\text { in } \mathrm{THF}}{\left(\mathrm{CH}_{3}\right)_{3} \mathrm{O}\left(\mathrm{BF}_{4}\right)} \rightarrow(\mathrm{CO})_{5} \mathrm{~W}=\mathrm{C}-\underset{\mathrm{OCH}}{-}-\left(\mathrm{CH}_{2}\right)_{2}-\mathrm{CH}=\mathrm{CH}_{2} \\
& \text { Yield, } 52 \%
\end{aligned}
$$

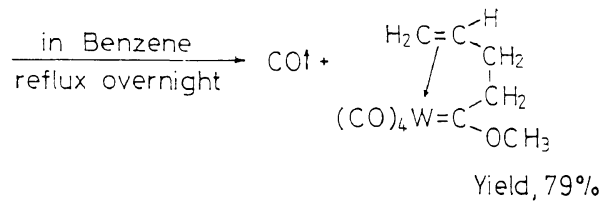

Scheme 1. Synthesis of the tungsten carbene complex.

bons $\delta 80.2,85.2$, and of $s p^{2}$ carbons $\delta 127.3$, $127.9,128.6,133.3,133.8$, and $142.8 \mathrm{ppm}$. In the ${ }^{29} \mathrm{Si} \mathrm{NMR}$ spectrum of monomer, there appears a signal of silyl silicon $(\delta-3.85 \mathrm{ppm})$, for which TMS was as an external reference.

\section{Catalyst Preparation}

The catalyst, tungsten carbene complex I, was prepared according to the method of Rudler $^{2,6}$ as shown in Scheme $1\left(\mathrm{mp} 77^{\circ} \mathrm{C}\right)$.

The crude solid obtained was purified on a chromatographic column of silica gel with hexane as the eluent and was recrystallized from pentane solution.

\section{Polymerization}

A typical polymerization procedure is as follows: Tungsten carbene complex catalyst $(0.01 \mathrm{~g})$ and solvent $\mathrm{CCl}_{4}(1.76 \mathrm{ml})$ were introduced into a Schlenk tube. The contents of the tube were flushed with nitrogen and sealed in vacuum by the freeze-thaw technique. The tube was kept in the dark and placed in a tank at a constant temperature $40^{\circ} \mathrm{C}$ for $15 \mathrm{~min}$. The monomer, $o$-trimethylsilyl phenylacetylene $(o$ $\left.\mathrm{Me}_{3} \mathrm{SiPA}, 0.50 \mathrm{ml}\right)$ was added to the solution by a syringe.

The mixture was kept in the dark at $40^{\circ} \mathrm{C}$ for $20 \mathrm{~h}$. The reaction solution was red and homogeneous at the beginning of polymerization, but gradually changed from red to dark purple. The polymerization reaction was termi- 
nated with a toluene-methanol (volume ratio $2: 1)$ mixture $(1 \mathrm{ml})$; the viscous solution was diluted with toluene $(10 \mathrm{ml})$ and poured into methanol $(1000 \mathrm{ml})$ with stirring to precipitate the dark purple polymer formed. The polymer was filtered and dried for about $24 \mathrm{~h}$ at $60^{\circ} \mathrm{C}$ under vacuum and weighed.

\section{Polymer Characterization}

The number and mass average molar masses $\left(\bar{M}_{n}\right.$ and $\left.\bar{M}_{w}\right)$ were determined by gel permeation chromatography (GPC). Four Waters (Ultrastyragel) columns $\left(300 \times 7.7 \mathrm{~mm} ; 10^{2}, 10^{3}\right.$, $10^{4}, 10^{5} \AA$ in a series) were used for GPC analysis with tetrahydrofuran (THF) $\left(1 \mathrm{ml} \mathrm{min}^{-1}\right)$ as the mobile phase. The eluents were monitored (Gilson Model 116) using light at $254 \mathrm{~nm}$ for the detection of benzene ring. Polystyrene was used as a standard.

A X-ray diffractogram was recorded with the powder method (Philips X-ray diffractometer, model PW 1710). For thermogravimetric analysis (Du Pont 9900 instrument) the heating rate was $10^{\circ} \mathrm{Cmin}^{-1}$.

Kinetic measurements were made following monomer concentration variation on a GC (Varian 3700) equipped with columns (PEG 6000,2 meters). Bromobenzene was used as the internal standard.

The polymer was characterized by IR, ${ }^{1} \mathrm{H}$ NMR, ${ }^{13} \mathrm{C}$ NMR, and ${ }^{29} \mathrm{Si}$ NMR spectra. IR: $v / \mathrm{cm}^{-1} \dot{\mathrm{C}}=\mathrm{C}, 1583, \mathrm{SiC}-\mathrm{H}, 1245, \mathrm{Si}-\mathrm{C}, 834$. ${ }^{1} \mathrm{H}$ NMR (in $\mathrm{CDCl}_{3}$ ): $\delta / \mathrm{ppm} 0.07(9 \mathrm{H}, \mathrm{Si}-$ $\left.\left(\mathrm{CH}_{3}\right)_{3}\right), 4.40-7.80(\mathrm{O},=\mathrm{CH}-) ;{ }^{13} \mathrm{C} \mathrm{NMR}$

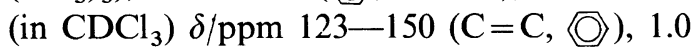
$\left(\mathrm{Si}\left(\mathrm{CH}_{3}\right)_{3}\right) ;{ }^{29} \mathrm{Si} \mathrm{NMR}$ (in $\left.\mathrm{CDCl}_{3}\right) \delta / \mathrm{ppm}$ $-5.90\left(\mathrm{Si}\left(\mathrm{CH}_{3}\right)_{3}\right)$. The formation of polymer was indicated by the characteristic absorption maximum $\left(\lambda_{\max } 541 \mathrm{~nm}, \varepsilon=11301 \cdot \mathrm{mol}^{-1}\right.$ $\mathrm{cm}^{-1}$ ).

\section{RESULTS AND DISCUSSION}

\section{Polymerization under Various Conditions}

The results of polymerization of $o$-trimethylsilyl phenylacetylene initiated with several cat- alysts are shown in Table I. At $60^{\circ} \mathrm{C}$, the coordinated carbene catalyst was clearly more efficient than other catalysts such as 2,2'azobisisobutyronitrile (AIBN), noncoordinated carbene or Fischer's catalyst. The polymer obtained with coordinated carbene catalyst easily dissolved in organic solvents .such as hexane, benzene and toluene, and chlorinated aliphatic hydrocarbon such as methylene chloride, chloroform and carbon tetrachloride. Table I shows that a greater yield and smaller molar mass of polymer were obtained when the polymerization was performed at a lower ratio of $[\mathrm{M}]_{0} /[\mathrm{I}]_{0}$ in toluene. When the polymerization was conducted with a Lewis acid such as $\mathrm{AlCl}_{3}$ (No. 7) or in nonpolar solvent such as $\mathrm{CCl}_{4}$ (No. 8) and $\mathrm{CHCl}_{3}$ (No. 9), poly $\left(o-\mathrm{Me}_{3} \mathrm{SiPA}\right)$ was quantitatively obtained with a large molar mass. Similar results were previously obtained for tert-butylacetylene with a tungsten carbene complex. ${ }^{4,5}$ Masuda et al. observed that the polymerization of tertbutylacetylene progressed with large yield in $\mathrm{CCl}_{4}$ by $\mathrm{WCl}_{6} \cdot{ }^{22}$ When polymerizations were performed in chlorinated aliphatic hydrocarbons such as methylene chloride and 1,2-dichloroethane, the polymer yield and molar mass decreased with increasing dipole moment of solvent. ${ }^{23} \mathrm{~A}$ higher yield and molar mass of polymer were obtained when we polymerized phenylacetylene in nonpolar solvents (e.g., hexane) than with polar solvents (e.g., $\mathrm{CH}_{2} \mathrm{Cl}_{2}$ ). This was also observed by Masuda for the polymerization of phenylacetylene catalyzed with $\mathrm{WCl}_{6} \cdot{ }^{24}$ Polar solvents (e.g., $\mathrm{CH}_{2} \mathrm{Cl}_{2}$ or $\mathrm{ClCH}_{2} \mathrm{CH}_{2} \mathrm{Cl}$ ) might decrease coordination between the tungsten carbene complex and monomer so to diminish the rate of polymerization. Moreover, when the solution of tungsten carbene complex in $\mathrm{CCl}_{4}$ was irradiated with UV light (250-W high-pressure mercury lamp) at $40^{\circ} \mathrm{C}$ for $60 \mathrm{~min}$, the molar mass was remarkably enhanced (No. 12, Table I). The catalyst solution irradiated with UV was deep red with fine black particles, possibly due to removal of the tungsten carbene complex (I) from 
Table I. Results of the polymerization of $o$-trimethylsilylphenylacetylene under various conditions ${ }^{\mathbf{a}}$

\begin{tabular}{|c|c|c|c|c|c|c|c|c|}
\hline \multirow{3}{*}{ No. } & \multirow{3}{*}{$\begin{array}{c}\text { Catalyst } \\
\text { [1] }\end{array}$} & \multirow{3}{*}{ Solvent } & \multirow{3}{*}{$\frac{[\mathrm{M}]_{0}}{[\mathrm{I}]_{0}}$} & \multirow{3}{*}{$\frac{\text { Temp. }}{{ }^{\circ} \mathrm{C}}$} & \multicolumn{3}{|c|}{ Polymer $^{\mathrm{b}}$} & \multirow{3}{*}{$\bar{M}_{w} / \bar{M}$} \\
\hline & & & & & \multirow{2}{*}{$\frac{\text { Yield }}{\%}$} & \multirow{2}{*}{$\begin{array}{c}\bar{M}_{n}^{\mathrm{c}} \\
\times 10^{-3}\end{array}$} & \multirow{2}{*}{$\begin{aligned} & \bar{M}_{w}{ }^{c} \\
& \times 10^{-3}\end{aligned}$} & \\
\hline & & & & & & & & \\
\hline 1 & AIBN & Toluene & 40 & 60 & 0 & - & - & \\
\hline 2 & Noncoordinated carbene ${ }^{d}$ & Toluene & 40 & 60 & 0 & - & - & \\
\hline 3 & Fischer catalyst ${ }^{\mathrm{e}}$ & Toluene & 40 & 60 & 0 & - & - & \\
\hline 4 & Coordinated carbene ${ }^{f}$ & Toluene & 10 & 60 & 53.5 & 2.4 & 6.9 & 2.88 \\
\hline 5 & Coordinated carbene $e^{f}$ & Toluene & 20 & 60 & 22.2 & 12 & 35 & 2.92 \\
\hline 6 & Coordinated carbene ${ }^{f}$ & Toluene & 40 & 60 & 8.4 & 22 & 63 & 2.86 \\
\hline 7 & Coordinated carbene $\mathrm{f}^{\mathrm{f}, \mathrm{g}}$ & Toluene & 40 & 30 & 99.1 & 163 & 538 & 3.30 \\
\hline 8 & Coordinated carbene $\mathrm{f}^{\mathrm{f}}$ & $\mathrm{CCl}_{4}$ & 100 & 30 & 100 & 91 & 189 & 2.08 \\
\hline 9 & Coordinated carbene ${ }^{f}$ & $\mathrm{CHCl}_{3}$ & 100 & 30 & 88.3 & 40 & 74 & 1.85 \\
\hline 10 & Coordinated carbene ${ }^{f}$ & $\mathrm{CH}_{2} \mathrm{Cl}_{2}$ & 100 & 30 & 25.0 & 26 & 56 & 2.15 \\
\hline 11 & Coordinated carbene $e^{f}$ & $\left(\mathrm{CH}_{2} \mathrm{Cl}\right)_{2}$ & 100 & 30 & 0 & - & - & \\
\hline 12 & Coordinated carbene $\mathrm{f}^{\mathrm{f}, \mathrm{h}}$ & $\mathrm{CCl}_{4}$ & 100 & 40 & 82.6 & 435 & 1145 & 2.63 \\
\hline
\end{tabular}

${ }^{\text {a }}$ Polymerization time, $24 \mathrm{~h} ;[\mathrm{M}]_{0}=1.0 \mathrm{moll}^{-1}$. ${ }^{\mathrm{b}}$ Methanol-insoluble product. ${ }^{\mathrm{c}}$ Measured by GPC in THF; polystyrene was used as the standard.

${ }^{\mathrm{d}}$ Noncoordinated carbene.

$$
\begin{array}{ll}
{ }^{d} \text { Noncoordinated carbene. } \\
(\mathrm{CO})_{5} \mathrm{~W}=\mathrm{C}_{-}^{-}(\mathrm{CH})_{2}-\mathrm{CH}=\mathrm{CH}_{2} \quad(\mathrm{CO})_{5} \mathrm{~W}=\mathrm{CH}_{3}={ }^{\mathrm{e}} \mathrm{OCH}_{3}
\end{array}
$$

${ }^{\mathbf{g}}$ Polymerization time, $20 \mathrm{~h} ;[\mathrm{M}]_{0}=1.0 \mathrm{moll}^{-1} . \mathrm{AlCl}_{3}$ was used as cocatalyst. $\left[\mathrm{AlCl}_{3}\right] /[\mathrm{I}]_{0}=12 .{ }^{\mathrm{h}}$ Tungsten carbene complex was irradiated in $\mathrm{CCl}_{4}$ for $60 \mathrm{~min}$ with a $365 \mathrm{~nm}$ Ushio $250 \mathrm{~W}$ high pressure mercury lamp at a distance of $5 \mathrm{~cm}$.

its coordinated bond and tungsten dichlorocarbene $\left(\begin{array}{l}\mathrm{Cl} \\ \mathrm{Cl}^{1}\end{array} \mathrm{C}=\mathrm{W}(\mathrm{CO})_{2}=\mathrm{C}=\right)$ immediately

forms from the reaction of tungsten carbene complex and $\mathrm{CCl}_{4}$ (Scheme 2, vide infra) and subsequently initiates polymerization. ${ }^{5,25,26}$

The effect of temperature on polymerization in $\mathrm{CCl}_{4}$ is shown in Table II. The polymer yield reached $100 \%$ at any temperature. The molar mass increased with temperature of polymerization.

Table III shows that the molar mass is a function of initial concentration of initiator (for $20 \mathrm{~h}$ ) in $\mathrm{CCl}_{4}$. The polymer yield reached $100 \%$ at any $[\mathrm{M}]_{0} /[\mathrm{I}]_{0}$ ratio. The moiar mass increased with decreasing initial concentration of initiator at a fixed concentration of mono-

\begin{tabular}{|c|c|c|c|c|}
\hline \multirow{3}{*}{$\frac{\text { Temp. }}{{ }^{\circ} \mathrm{C}}$} & \multicolumn{3}{|c|}{ Polymer ${ }^{b}$} & \multirow{3}{*}{$\bar{M}_{w} / \bar{M}_{n}$} \\
\hline & Yield & \multirow{2}{*}{$\begin{array}{c}\bar{M}_{n}^{\mathrm{c}} \\
\times 10^{-3}\end{array}$} & \multirow{2}{*}{$\begin{array}{c}\bar{M}_{w}{ }^{\mathrm{c}} \\
\times 10^{-3}\end{array}$} & \\
\hline & $\%$ & & & \\
\hline 30 & 100 & 92 & 189 & 2.05 \\
\hline 40 & 100 & 128 & 208 & 1.63 \\
\hline 60 & 100 & 226 & 575 & 2.54 \\
\hline 80 & 100 & 257 & 585 & 2.28 \\
\hline
\end{tabular}

Table II. Effects of temperature on the polymerization of $o-\mathrm{Me}_{3} \mathrm{SiPA}$ in $\mathrm{CCl}_{4}{ }^{\mathrm{a}}$

a Polymerization time, $24 \mathrm{~h} ;[\mathrm{M}]_{0}=1 \mathrm{moll}^{-1} ;[\mathrm{M}]_{0} /$ $[\mathrm{I}]_{0}=100$. ${ }^{\mathrm{b}}$ Methanol-insoluble product. ${ }^{\mathrm{c}}$ Measured by GPC in THF; polystyrene was used as standard.

mer.

Figure 1 shows variation of the mass-average molar mass $\left(\bar{M}_{w}\right)$ with varied ratio $[\mathrm{M}]_{0} /[\mathrm{I}]_{0}$ during polymerization $\bar{M}_{w}$ increased first with 
Table III. Effects of the initial tungsten carbene complex concentration $[\mathrm{I}]_{0}$ on the polymerization of $o-\mathrm{Me}_{3} \mathrm{SiPA}$ in $\mathrm{CCl}_{4}$ at $40^{\circ} \mathrm{C}^{\mathrm{a}}$

\begin{tabular}{|c|c|c|c|c|}
\hline \multirow{3}{*}[\mathrm{M}]{$_{0} /[\mathrm{I}]_{0}$} & \multicolumn{3}{|c|}{ Polymer $^{\mathrm{b}}$} & \multirow{3}{*}{$\bar{M}_{w} / \bar{M}_{n}$} \\
\hline & Yield & \multirow{2}{*}{$\begin{array}{c}\bar{M}_{n}^{\mathrm{c}} \\
\times 10^{-3}\end{array}$} & \multirow{2}{*}{$\begin{aligned} & \bar{M}_{w}{ }^{\mathrm{c}} \\
& \times 10^{-3}\end{aligned}$} & \\
\hline & $\%$ & & & \\
\hline 100 & 100 & 128 & 208 & 1.63 \\
\hline 60 & 100 & 114 & 188 & 1.65 \\
\hline 40 & 100 & 75 & 98 & 1.31 \\
\hline 20 & 100 & 46 & 81 & 1.76 \\
\hline
\end{tabular}

${ }^{\text {a }}$ Polymerization time, $20 \mathrm{~h} ;[\mathrm{M}]_{0}=1 \mathrm{moll}^{-1}$. ${ }^{\mathrm{b}}$ Methanol-insoluble product. ${ }^{c}$ Measured by GPC in THF; polystyrene was used as the standard.

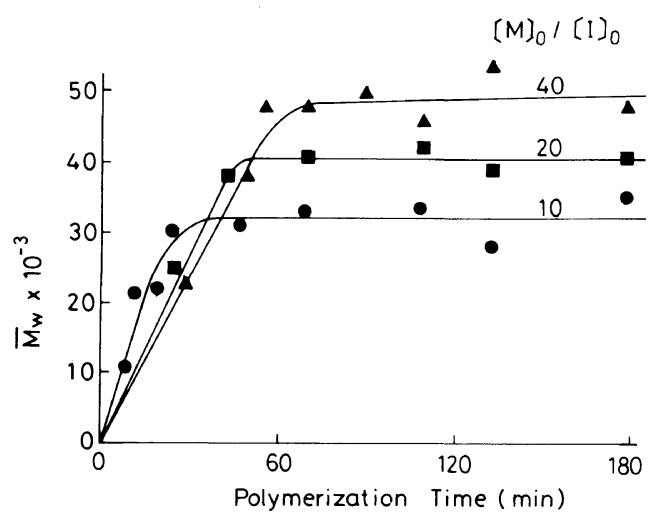

Figure 1. Relationship between $\bar{M}_{w}$ of poly $\left(o-\mathrm{Me}_{3} \mathrm{SiPA}\right)$ and polymerization time at $40^{\circ} \mathrm{C}$ in $\mathrm{CCl}_{4}$ solution. The ratio $[\mathrm{M}]_{0} /[\mathrm{I}]_{0}, 10(\bullet), 20(\mathbf{\square}), 40(\mathbf{\Delta}) \cdot[\mathrm{M}]_{0}=1 \mathrm{moll}^{-1}$.

conversion up to an asymptotic values and remained constant until the end of polymerization regardless of the value of $[\mathrm{M}]_{0} /[\mathrm{I}]_{0}$. The polymerization by tungsten carbene complex approached approximately $90 \%$ conversion in $3 \mathrm{~h}\left([\mathrm{M}]_{0} /[\mathrm{I}]_{0}=40\right)$. That the molar mass remained constant after $60 \mathrm{~min}$ might be explained by the occurrence of termination reactions and also by the existence of transfer reactions in the course of polymerization, as reported by Fontanille et al. ${ }^{27}$ using a binuclear complex of a tungsten catalytic system.

The effect of temperature on the molar mass

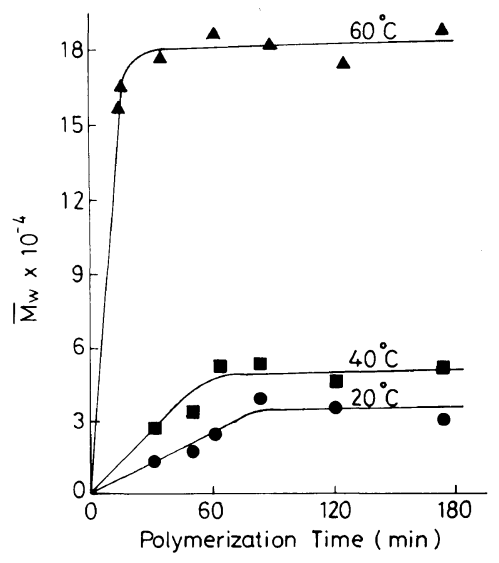

Figure 2. Effects of temperature on the $\bar{M}_{w}$ of the polymerization of $o-\mathrm{Me}_{3} \mathrm{SiPA}$, the ratio $[\mathrm{M}]_{0} /[\mathrm{I}]_{0}=40$ in $\mathrm{CCl}_{4}$ solution. (O) $20^{\circ} \mathrm{C}$; (口) $40^{\circ} \mathrm{C} ;(\boldsymbol{\Delta}) 60^{\circ} \mathrm{C}$. $[\mathrm{M}]_{0}=$ $1 \mathrm{moll}^{-1}$.

in the polymerization of $o$-trimethylsilylphenylacetylene is shown in Figure 2. The curve resembles that of Figure 1. The mass average molar mass increases with temperature of polymerization. This indicates that as the temperature is raised, the catalytic activity may be significantly enhanced. The molar mass increased first with conversion up to asymptotic values during the initial stage of polymerization, then remained constant until the end of polymerization due to termination and transfer reactions. $^{27}$

As mentioned-above (Table I, No. 7) a Lewis acid such as $\mathrm{AlCl}_{3}$ enhanced the molar mass and yield of the polymer. Table IV shows the effects of other cocatalysts on the polymerization of $o-\mathrm{Me}_{3} \mathrm{SiPA}$ by tungsten carbene complex. The polymer yield reached $100 \%$ regardless of the concentration of $\mathrm{SnCl}_{4}$ in $\mathrm{CCl}_{4}$. However, the molar mass increased with concentration of $\mathrm{SnCl}_{4}$, and showed maximal values for $\left[\mathrm{SnCl}_{4}\right] /[\mathrm{I}]_{0}=1$. The variation of molar masses in Table 4 shows that the tungsten carbene complex was affected by the aluminum cocatalyst in the following order: $\left(\mathrm{C}_{2} \mathrm{H}_{5}\right)_{1.5} \mathrm{AlCl}_{1.5}>\left(\mathrm{C}_{2} \mathrm{H}_{5}\right)_{2} \mathrm{AlCl}>\left(\mathrm{C}_{2} \mathrm{H}_{5}\right)_{3} \mathrm{Al}$, corresponding to the order of the Lewis acidity, $\left(\mathrm{C}_{2} \mathrm{H}_{5}\right)_{1.5} \mathrm{AlCl}_{1.5}>\left(\mathrm{C}_{2} \mathrm{H}_{5}\right)_{2} \mathrm{AlCl}>\left(\mathrm{C}_{2} \mathrm{H}_{5}\right)_{3^{-}}$ 
Table IV. Effects of cocatalysts on the polymerization of $o-\mathrm{Me}_{3} \mathrm{SiPA}$ by the tungsten carbene complex catalyst [I]

\begin{tabular}{|c|c|c|c|c|c|}
\hline \multirow{3}{*}{ Cocatalyst } & \multirow{3}{*}{$\frac{[\text { Cocatalyst }]}{[\mathrm{I}]_{0}}$} & \multicolumn{3}{|c|}{ Polymer $^{\mathbf{a}}$} & \multirow{3}{*}{$\bar{M}_{w} / \bar{M}_{n}$} \\
\hline & & \multirow{2}{*}{$\begin{array}{c}\text { Yield } \\
\%\end{array}$} & \multirow{2}{*}{$\begin{array}{c}\bar{M}_{n}^{\mathrm{b}} \\
\times 10^{-3}\end{array}$} & \multirow{2}{*}{$\begin{array}{c}\bar{M}_{w}{ }_{w}^{b} \\
\times 10^{-3}\end{array}$} & \\
\hline & & & & & \\
\hline $\mathrm{SnCl}_{4}{ }^{\mathrm{c}}$ & 0.0 & 100 & 128 & 208 & 1.63 \\
\hline $\mathrm{SnCl}_{4}{ }^{\mathrm{c}}$ & 0.6 & 100 & 139 & 284 & 2.04 \\
\hline $\mathrm{SnCl}_{4}{ }^{\mathrm{c}}$ & 1.0 & 100 & 194 & 387 & 1.99 \\
\hline $\mathrm{SnCl}_{4}{ }^{\mathrm{c}}$ & 2.0 & 100 & 139 & 272 & 1.96 \\
\hline $\mathrm{SnCl}_{4}{ }^{\mathrm{c}}$ & 3.0 & 91 & 79 & 177 & 2.24 \\
\hline$\left(\mathrm{C}_{2} \mathrm{H}_{5}\right)_{1.5} \mathrm{AlCl}_{1.5}{ }^{\mathrm{d}}$ & 1.0 & 100 & 46 & 83 & 1.80 \\
\hline$\left(\mathrm{C}_{2} \mathrm{H}_{5}\right)_{2} \mathrm{AlCl}^{\mathrm{d}}$ & 1.0 & 10 & 6 & 11 & 1.83 \\
\hline$\left(\mathrm{C}_{2} \mathrm{H}_{5}\right)_{3} \mathrm{Al}^{\mathrm{d}}$ & 1.0 & 7 & - & - & \\
\hline
\end{tabular}

${ }^{a}$ Methanol-insoluble product. ${ }^{b}$ Measured by GPC in tetrahydrofuran (THF); polystyrene was used as the standard. ${ }^{\mathrm{c}}$ Polymerized in $\mathrm{CCl}_{4}$ at $40^{\circ} \mathrm{C}$ for $20 \mathrm{~h} ;[\mathrm{M}]_{0}=1.0 \mathrm{moll}^{-1} ;[\mathrm{M}]_{0} /[\mathrm{I}]_{0}=100$. ${ }^{\mathrm{d}}$ Polymerized in toluene at $40^{\circ} \mathrm{C}$ for $20 \mathrm{~h}$; $[\mathrm{M}]_{0}=1.0 \mathrm{moll}^{-1} ;[\mathrm{M}]_{0} /[\mathrm{I}]_{0}=100$.

Al. ${ }^{28}$ Thus, the cocatalyst with the best acceptor properties appeared to be the most active. This is possibly due to cocatalyst complex formation with the $\mathrm{CO}$ ligand of the initiator. Such complexation would induce a decrease of the intramolecular coordination of the double bond. The mechanism of the polymerization of alkynes initiated by initiator (I) would eventually be the decoordination of the ethylenic bond followed by complexation of the monomer.

\section{Mechanism of Polymerization}

The mechanism of polymerization of $o$-trimethylsilylphenylacetylene is proposed in Scheme 2. First, with carbene complex I in $\mathrm{CCl}_{4}$, the carbene complex $\mathrm{I}$ is removed from its coordinated bond and tungsten dichlorocarben II may be immediately formed. Then the intramolecularly coordinated bond in the catalyst $I$ is replaced by the triple bond of the monomer leading to complex III. The next step is the insertion through a metallacyclobutene intermediate IV leading to the first carbenic active center $\mathrm{V}$. The existence of intermediate IV has been proposed by several authors. $^{1,8,10,24}$ The intermediate has been isolated and characterized in the case of titanium and tungsten complexes, by Grubbs et al. ${ }^{29}$ and Ivin et al., ${ }^{30}$ respectively. The first step is bimolecular and agrees with the initial kinetic order relative to monomer and initiator I to be described later. The new metal carbene complex $\mathrm{V}$ is highly reactive due to the absence of a heteroatom at the carbenic carbon and cannot be isolated. ${ }^{8}$ Carbene complex $\mathrm{V}$ is able to induce polymerization through a steadystate process. ${ }^{31,32}$

\section{Kinetic Experiments}

To obtain the apparent rate constant $\left(k_{\text {app }}\right)_{0}$, the kinetic order of the rate equation was determined by GC. The initially maximal rates of polymerization $\left(R_{\mathrm{p}}\right)_{0}$ were determined at initial stages of polymerization. In order to determine the kinetic order of the monomer, the catalyst concentration $\left([\mathrm{I}]_{0}\right)$ was fixed and the monomer concentration $\left([\mathrm{M}]_{0}\right)$ was varied from 0.318 to $0.826 \mathrm{moll}^{-1}$ at $40^{\circ} \mathrm{C}$ in $\mathrm{CCl}_{4}$. The results are shown in Figure 3.

The rate of polymerization was proportional to the monomer concentration. A similar test was carried out to determine the kinetic order of the catalyst [I] ranging from $2.9 \times 10^{-3}$ to 


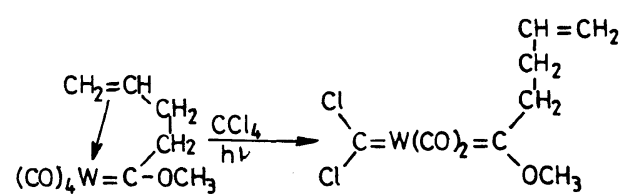

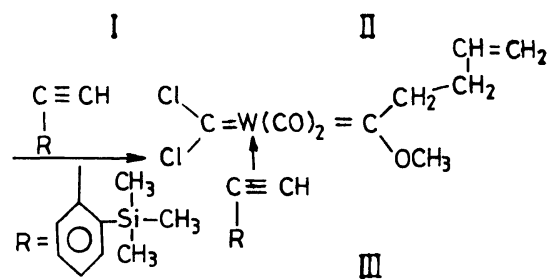

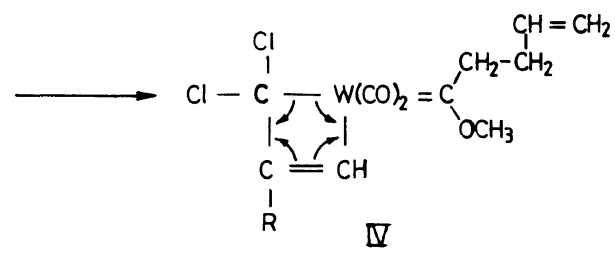<smiles></smiles>

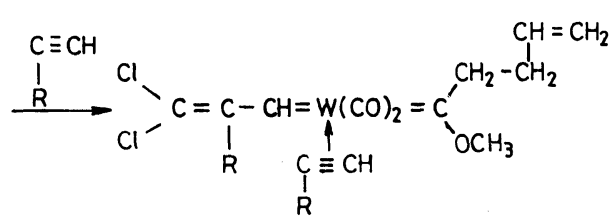$$
\text { - - - P Polymer }
$$

Scheme 2. Mechanism for the polymerization of $o$-trimethylsilyl phenylacetylene.

$15.0 \times 10^{-3} \mathrm{moll}^{-1}$ at $40^{\circ} \mathrm{C}$ in $\mathrm{CCl}_{4}$. The results appear in Figure 4. The kinctic order of the catalyst is also unity. Thus, the rate of polymerization of $o$-trimethylsilylphenylacetylene may be determined as follows:

$$
\left(R_{\mathrm{p}}\right)_{0}=\left(k_{\text {app }}\right)_{0} \times[\mathrm{M}]_{0}[\mathrm{I}]_{0}=-\mathrm{d}[\mathrm{M}] / \mathrm{d} t
$$

in which $\left(R_{\mathrm{p}}\right)_{0}$ is the apparent rate of polymerization and $\left(k_{\text {app }}\right)_{0}$ is the apparent rate constant. At other temperatures, the rates of polymerization were proportional to the concentrations of monomer and catalyst. The results of the initial apparent rate of polym-

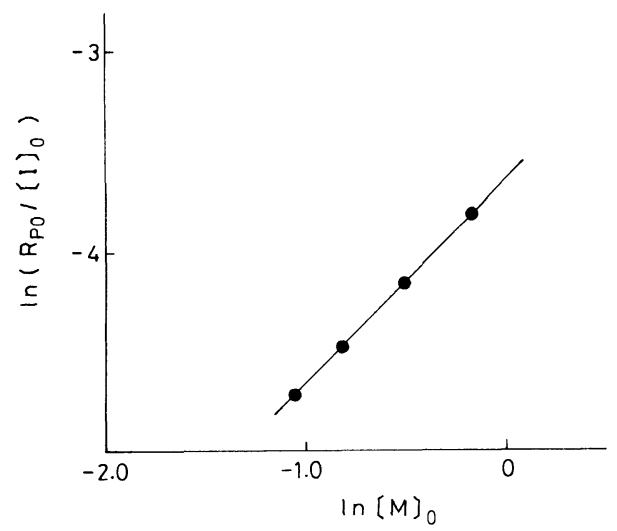

Figure 3. Kinetics of the addition of $o-\mathrm{Me}_{3} \mathrm{SiPA}$ to the catalyst at $40^{\circ} \mathrm{C}$ in $\mathrm{CCl}_{4}$. Determination of kinetic order with respect to monomer, $[\mathrm{I}]_{0}=6 \times 10^{-3} \mathrm{moll}^{-1}$.

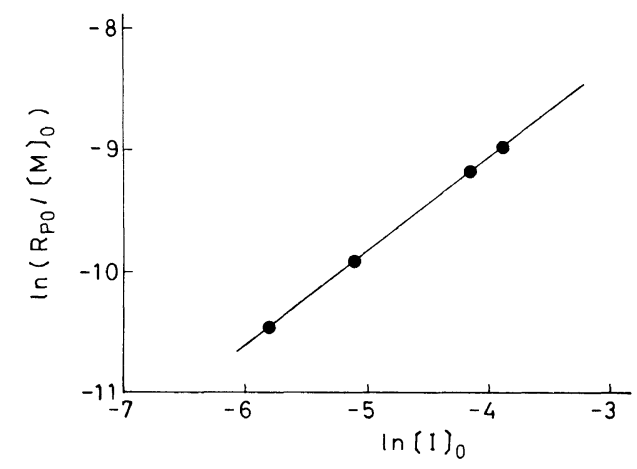

Figure 4. Kinetics of the addition of $o-\mathrm{Me}_{3} \mathrm{SiPA}$ to the catalyst at $40^{\circ} \mathrm{C}$ in $\mathrm{CCl}_{4}$. Determination of kinetic order with respect to catalyst, $[\mathrm{M}]_{0}=0.60 \mathrm{moll}^{-1}$.

Table V. Initial apparent rates $\left(R_{\mathrm{p}}\right)_{0}$ and constants $\left(k_{\text {app }}\right)_{0}$ for the polymerization of $o-\mathrm{Me}_{3} \mathrm{SiPA}$ initiated by the tungsten carbene complex catalyst at various temperatures in $\mathrm{CCl}_{4}{ }^{\mathrm{a}}$

\begin{tabular}{ccccc}
\hline Temperature & & $\left(R_{\mathrm{p}}\right)_{0} \times 10^{5}$ & & $\left(k_{\mathrm{app}}\right)_{0} \times 10^{3}$ \\
\cline { 1 - 1 }${ }^{\circ} \mathrm{C}$ & & $\mathrm{moll}^{-1} \mathrm{~s}^{-1}$ & & $1 \cdot \mathrm{mol}^{-1} \mathrm{~s}^{-1}$ \\
\hline 50 & 10.8 & & 44.6 \\
45 & & 4.0 & & 16.5 \\
40 & & 2.5 & & 10.3 \\
30 & 1.7 & & 6.9 \\
\hline
\end{tabular}

${ }^{\mathrm{a}}[\mathrm{M}]_{0}=0.583 \mathrm{mol1}^{-1} ;[\mathrm{M}]_{0} /[\mathrm{I}]_{0}=140$.

erization $\left(R_{\mathrm{p}}\right)_{0}$ and rate constants $\left(k_{\mathrm{app}}\right)_{0}$ in $\mathrm{CCl}_{4}$ are presented in Table V. Both $\left(R_{\mathrm{p}}\right)_{0}$ and $\left(k_{\text {app }}\right)_{0}$ increased with temperatures. The 


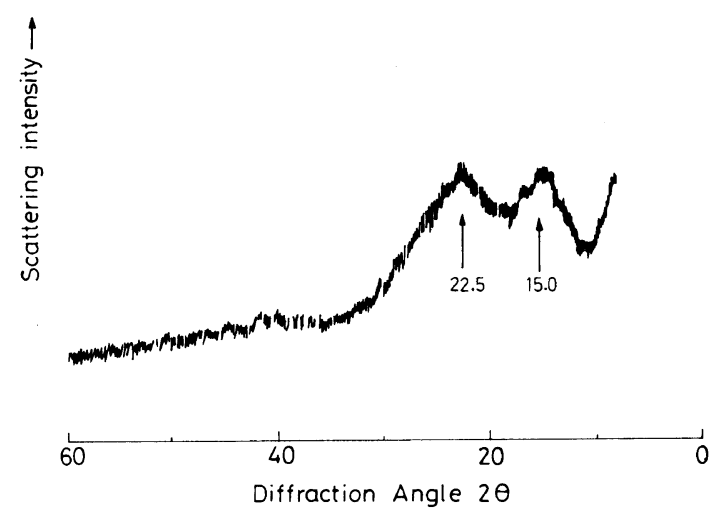

Figure 5. X-Ray diffraction diagram of poly $(o-$ $\mathrm{Me}_{3} \mathrm{SiPA}$ ).

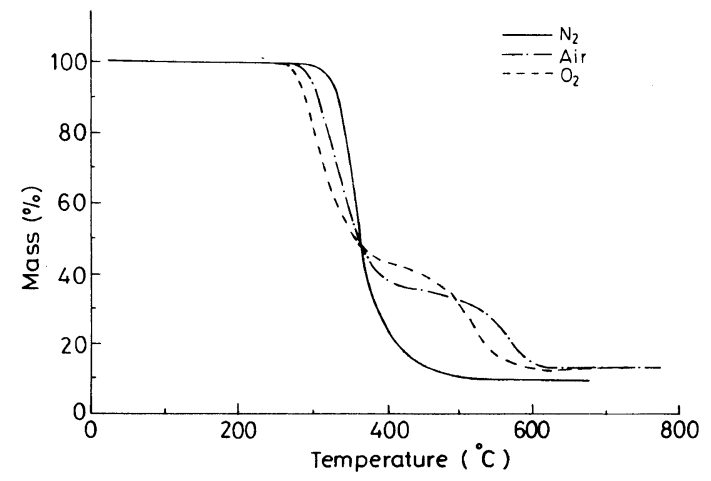

Figure 6. TGA curves for poly $\left(o-\mathrm{Me}_{3} \mathrm{SiPA}\right)$ in nitrogen, air and oxygen. (Heating rate $10^{\circ} \mathrm{Cmin}^{-1}$.)

activation enthalpy $\left(\triangle H_{\mathrm{p}}\right)$ and entropy $\left(\triangle S_{\mathrm{p}}\right)$ of the propagation reaction were calculated as $69.7 \mathrm{~kJ} \mathrm{~mol}^{-1}$ and $-66.2 \mathrm{~J} \mathrm{~mol}^{-1} \mathrm{~K}^{-1}$, respectively.

Properties and Structure of Poly $\left(o-\mathrm{Me}_{3} \mathrm{SiPA}\right)$

Figure 5 shows a X-ray diffractogram of poly $\left(o-\mathrm{Me}_{3} \mathrm{SiPA}\right)$. The broad diffraction lines at $2 \theta=15.0^{\circ}$ and $22.5^{\circ}$ indicate that poly $(o-$ $\left.\mathrm{Me}_{3} \mathrm{SiPA}\right)$ obtained from tungsten carbene complex has an amorphous structure.

Figure 6 shows the TGA curves of poly $(o-$ $\mathrm{Me}_{3} \mathrm{SiPA}$ ) obtained from room temperature to $800^{\circ} \mathrm{C}$. Loss of mass of poly $\left(o-\mathrm{Me}_{3} \mathrm{SiPA}\right)$ occurred above $300^{\circ} \mathrm{C}$ in nitrogen. The polymer was stable at room temperature in air for six months. In the presence of oxygen, the onset
Table VI. Changes in number-average molar mass $\left(\bar{M}_{n}\right)$ on heating poly $\left(o-\mathrm{Me}_{3} \mathrm{SiPA}\right)$ in presence of air at $200^{\circ} \mathrm{C}$

\begin{tabular}{lcc}
\hline Heat treatment & $\bar{M}_{n} \times 10^{-4}$ & $\bar{M}_{w} / \bar{M}_{n}$ \\
\hline Before & 18.9 & 2.1 \\
After 1 h & 7.53 & 2.3 \\
After 2h & 4.08 & 2.4 \\
\hline
\end{tabular}

of mass loss of poly $\left(o-\mathrm{Me}_{3} \mathrm{SiPA}\right)$ occurred at a slightly lower temperature than in nitrogen. At temperatures above $360^{\circ} \mathrm{C}$, the curves of loss of mass of poly $\left(o-\mathrm{Me}_{3} \mathrm{SiPA}\right)$ in nitrogen and in the presence of oxygen showed large differences. In the presence of oxygen, the decrease of mass slowed down considerably between 400 and $460^{\circ} \mathrm{C}$ before a second rapid mass loss step occurs. The amount of residue remaining at $700^{\circ} \mathrm{C}$ increased and the white residue was probably $\mathrm{SiO}_{2}$. This was also observed by Tang et al. ${ }^{33}$ and Neoh et al. ${ }^{34}$

Table VI shows the number average molar mass $\left(\bar{M}_{n}\right)$ changes with the heat treatment of $\operatorname{poly}\left(o-\mathrm{Me}_{3} \mathrm{SiPA}\right)$ in the presence of air at $200^{\circ} \mathrm{C}$ for $2 \mathrm{~h}$.

The molar mass apparently decreased with heating for $1 \mathrm{~h}$ or $2 \mathrm{~h}$ above $200^{\circ} \mathrm{C}$ in air. The shapes of the molar mass distribution curves before and after thermal treatment scarcely altered for this polymer, which indicates that degradation takes place randomly. At a low temperature of degradation $\left(200^{\circ} \mathrm{C}\right)$, the effect of oxidation was not readily detected in the IR spectra. Neoh et al. ${ }^{34}$ reported that the IR absorption spectrum of the poly $\left(o-\mathrm{Me}_{3} \mathrm{SiPA}\right)$ sample after heating to $270^{\circ} \mathrm{C}$ is similar to that of the original sample. However, when the sample was heated to $430^{\circ} \mathrm{C}$, the spectrum showed lines due to oxygen-containing groups, such as $\mathrm{O}-\mathrm{H}, \mathrm{C}=\mathrm{O}$, and $\mathrm{Si}-\mathrm{O}$.

The polymer had the form of a dark purple solid $\left(\lambda_{\max } 541 \mathrm{~nm}\right)$, dissolved completely in common organic solvents such as hexane, toluene, and $\mathrm{CHCl}_{3}$ etc. and formed a strong, free-standing film on solution casting. 
Acknowledgment. The authors thank the National Science Council of the Republic of China for financial supports under grant NSC-82-0405-E011-164. We also thank Professor T. Masuda, Kyoto University, Japan for useful discussions, Professor Fontanille and Soum, Bordeaux University, France for their comments and B. H. Jin for technical assistance.

\section{REFERENCES}

1. D. J. Liaw, S. D. Leu, C. L. Lin, and C. F. Lin, Polym. J., 24, 889 (1992).

2. D. J. Liaw, A. Soum, M. Fontanille, A. Parlier, and H. Rudler, Makromol. Chem., Rapid Commun., 6, 309 (1985).

3. D. J. Liaw, C. Lucas, A. Soum, M. Fontanille, A. Parlier, and H. Rudler, in "Transition Metal Catalyzed Polymerization," R. P. Quirk, Ed., Cambridge University Press, Cambridge, Mass., 1988, pp 671-687.

4. D. J. Liaw and C. L. Lin, J. Polym. Sci., Polymer Chem. Ed., 31, 3151 (1993).

5. D. J. Liaw and C. L. Lin, Polym. Int., 36, 29 (1995).

6. C. Alvarez, J. Levisalles, M. Rudler, H. Rudler, J. C. Daran, and Y. Jeannin, J. Organomet. Chem., C7, 228 (1982).

7. A. Parlier, H. Rudler, N. Platzer, A. Soum, and M. Fontanille, J. Chem. Soc., Dalton Trans., 1041 (1987).

8. C. Lucas, A. Soum, and M. Fontanille, Makromol. Chem., 19, 377 (1989).

9. G. Costa, in "Comprehensive Polymer Science," Vol 4, G. Allen, Ed., Pergamon, Oxford, 1989, Chapter 9.

10. T. Masuda and T. Higashimura, Adv. Polym. Sci., 81, 121 (1987).

11. Y. Ichiraka, S. Stern, and T. Nakagawa, J. Membrane Sci., 34, 5 (1987).

12. T. Masuda, Y. Iguchi, B. Z. Tang, and T. Higashimura, Polymer, 29, 2041 (1988).

13. T. Masuda, B. Z. Tang, and T. Higashimura, Polym. J., 18, 565 (1986).

14. K. Ishihara, Y. Nagase, and K. Matsui, Makromol. Chem. Rapid Commun., 7, 43 (1986).
15. T. Masuda, T. Hamano, K. Tsuchihara, and T. Higashimura, Macromolecules, 23, 1374 (1990).

16. E. T. Kang, K. G. Neoh, T. Masuda, T. Higashimura, and M. Yamamoto, Polymer, 30, 1328 (1989).

17. L. Brandsma and H. D. Verkruijsse, "Studies in Organic Chemistry 8; Synthesis of Acetylenes, Allenes and Cumulenes, Elsevier, Amsterdam, 1981, p 85.

18. K. G. Neoh, E. T. Kang, and K. L. Tan, Polymer, 32, 226 (1991).

19. R. M. Silverstein, G. C. Bassler, and T. C. Morril, "Spectrometric Identification of Organic Compounds," Wiley, New York, N.Y., 1980, Chapter 3.

20. N. B. Colthup, L. H. Daly, and S. E. Wiberley, "Introduction to Infrared and Raman Spectroscopy," Academic Press, New York, N.Y., 1975.

21. J. Kunzler and V. Percec, J. Polym. Sci., Polym. Chem. Ed., 28, 1221 (1990).

23. J. A. Riddick and W. B. Bunger, "Organic Solvents," 3rd ed., Wiley-Interscience, New York, N.Y., 1970, pp 349, 350, 352, and 356.

24. T. Masuda, N. Sasaki, and T. Higashimura, Macromolecules, 8, 717 (1975).

25. F. Garnier, P. Krausz, and H. Rudler, J. Organomet. Chem., 186, 77 (1980).

26. T. Masuda and T. Higashimura, Adv. Polym. Sci., 81, 121 (1987).

27. D. Meziane, A. Soum, and M. Fontanille, Makromol. Chem., 189, 1407 (1988).

28. I. M. Baibich, A. Parlier, H. Rudler, M. Fontanille, C. Lucas, and A. Soum, J. Molecular Catalysis, 53, 193 (1988).

29. L. R. Gilliom and R. H. Grubbs, J. Am. Chem. Soc., 108, 733 (1986).

30. J. Kress, J. A. Osborn, R. M. Greene, K. J. Ivin, and J. J. Rooney, J. Am. Chem. Soc., 109, 899 (1987).

31. A. Soum and M. Fontanille, in "Advances on Mechanistic and Synthetic Aspects in Polymerization," M. Fontanille and A. Guyot, Ed., Reidel Publishing Company, Dordrecht, Netherland, 1987.

32. M. Fontanille, C. Lucas, and A. Soum, Makromol. Chem., 193, 411 (1992).

33. B. Z. Tang, T. Masuda, T. Higashimura, and $\mathrm{H}$. Yamaka, J. Polym. Sci., Polym. Chem. Ed., 27, 1197 (1989).

34. K. G. Neoh, E. T. Kang, and K. L. Tan, Polym. Degradation and Stability, 29, 279 (1990). 